\title{
Food Handling Practices and Microbial Quality in Street Food
}

\author{
Jhenifer de Souza Couto Oliveira, Jackline Freitas Brilhante de São José* \\ Federal University of Espírito Santo, Post-Graduation Program in Nutrition and Health, \\ Center of Health Sciences, Avenida Marechal Campos, 1468, Maruípe, Vitória-ES, Brazil \\ *Corresponding author: jackline.jose@ufes.br
}

Received February 01, 2019; Revised March 11, 2019; Accepted April 18, 2019

\begin{abstract}
The great relevance of evaluating the sanitary-hygienic conditions in the street food vending sites, as a means to identify risks and prevent food-originated diseases. In this paper, street food trades are analyzed in Vitória, Espírito Santo, Brazil. To accomplish this, a study of a cross-sectional, observational and descriptive kind was carried out from July 2016 to March 2017. Good practice checklists based on legislation and research were applied in that group of street vendors and 20 samples of the food commercialized were analyzed. The places visited presented average adequacy equal to $44 \%$, as from the analysis of the checklists, various items pointing to the need for improvement, mainly in relation to sanitary license and environmental conditions. Coliforms at $35^{\circ} \mathrm{C}$, molds and yeasts, as well as Staphylococcus spp. were detected in all food samples analyzed, hot dogs standing out as the food with the highest microbial load. This indicates that the organizations must supervise sanitary conditions and offer to street food vendors education programs to contribute to adequate hygiene practices. This is essential to improve the quality of the foods sold in the streets and prevent foodborne diseases.
\end{abstract}

Keywords: food hygiene; food handling; public health, contamination, quality control

Cite This Article: Jhenifer de Souza Couto Oliveira, and Jackline Freitas Brilhante de São José, "Food Handling Practices and Microbial Quality in Street Food." Journal of Food and Nutrition Research, vol. 7, no. 4 (2019): 319-324. doi: 10.12691/jfnr-7-4-9.

\section{Introduction}

The number of people who choose to eat outside home is increasing. This type of food is gaining more space in the market due to the practicality and time saving it offers [1]. Thus, there was an increase consumption of meals in restaurants, snack bars and in street trades [2]. Street food can be located near to car parks, railway stations, hospitals, schools, office centers and marketplaces [3]. Street foods are popular among urban people because they are cheap, convenient and attractive $[2,4]$. Street foods are defined as "foods and beverages prepared and/or sold by vendors in streets and other public places for immediate consumption or consumption at a later time without further processing or preparation" [4].

Currently, street food is common in most cities and towns in developing and developed countries. In areas where the local economy is experiencing serious crises, it is possible to easily verify the progress of the itinerant food trade. People start adopting sale food as a source of extra income, which assists in the home economy and may be the only means of obtaining income from unemployed individuals. People with a low level of education and who have difficulties and restrictions on getting a job find mobile commerce an opportunity to generate income $[2,3]$. However, food marketed in the streets causes great concern to food safety agencies due to inappropriate and poor conditions of production and sale verified in some trades [5].

The control of food quality is fundamental, as inadequate hygiene practices of food handlers and food preparation environments can lead to contamination of food [8]. From 2007 to 2016, 6,632 outbreaks of Foodborne Illness (DOA) were reported in Brazil, 118,104 patients, 17,186 hospitalizations due to DOAs and 109 deaths; $43.8 \%$ of reported outbreaks occurred in the Southeast Region and the main signs and symptoms reported were diarrhea, abdominal pain, vomiting and nausea [9]. To prevent the occurrence of these diseases, it is necessary to implement good practices in food services. Norms and procedures for proper food handling should be considered in preparation [10]. Thus, the microbiological characteristics of ready-to-eat food may be a consequence of the practice or not of good practices, resulting in the inadequate sanitary quality of foods $[10,11]$.

Street food trade is still unregulated in some places. A specific legislation regarding the preparation, preservation and sale of this type could help to guarantee food safety. In this sense, it is important to carry out studies to evaluate hygienic sanitary conditions of street food marketing, since they are, in most cases, perishable, ready for consumption and are a reality Brazil [12]. The objective of this study was to evaluate the hygienic and sanitary conditions of street food trades in the city of Vitória, ES, Brazil. 


\section{Material and Methods}

A cross-sectional, exploratory and descriptive study was carried out, in which, from July 2016 to March 2017. 60 street food trades located in Vitória-ES were evaluated and each trade were visited once time. Since it is informal commerce without registration of the total quantity, the choice of locations was convenient. Itinerant sampling was performed to compose the study population. Wandering trades located in regions of great flow of people were chosen, such as in the vicinity of hospitals, leisure plazas, universities, schools and on the seafront of the city. The application of the checklist was carried out in point of sale, without prior notification. The researchers performed the information in an observational way following checklist's items.

\subsection{Assessment of Good Handling Practices}

The data were collected through a checklist of good practices structured with 35 items based on Resolution 216/2004 [13] and research developed by Torres [14] e Pierre [15]. The list is divided into two parts: trade identification and evaluation of hygienic and sanitary conditions. This list was composed of items related to the conditions of the trolleys (tents), equipment and utensils used in the preparation and manipulation of food ( 8 items); food handlers (6 items); good practices in food handling (17 items); environmental conditions surrounding the trade (3 items) and information related to the sanitary license (1 item). Each item had three possible answers: "C" - Conform/Adequate; "NC" - Not compliant / Inadequate; "NA" - Not apply.

\subsection{Microbiological Quality of Food}

After the application of the checklist, the main foods commercialized were identified and samples of these were collected. Food was collected during without prior notification and was obtained in the form of purchase. Researchers responsible for collecting the samples packed the food in previously sterilized plastic bags and transported in isothermal boxes. The samples were kept under refrigeration at $7^{\circ} \mathrm{C} \pm 1^{\circ} \mathrm{C}$, for a maximum of 24 hours until the analysis. Each food trades sold one of the types of foods selected for microbiological analysis.

The procedures used in this step were performed according to the methodology of the American Public Health Association (APHA), described in the Compendium of Methods for the Microbiological Examination of Foods [16]. Sample $(25 \mathrm{~g})$ was weighed and $225 \mathrm{~mL}$ of $0.1 \%$ peptone water sterilized was added. After this, appropriate decimal dilutions were prepared and aliquots of those were transferred to specific culture media for the determination of each microbial group. Coliforms $35{ }^{\circ} \mathrm{C}$ and Escherichia coli were performed by the Petrifilm ${ }^{\mathrm{TM}}$ technique (3M® Company, St. Paul, MN, USA), following the recommendations of the Association of Official Analytical Chemists [17]. Plates were incubated at $35^{\circ} \mathrm{C}$ for $48 \mathrm{~h}$ and result was expressed in CFU/g. For analysis of Staphylococcus spp., Baird Parker Agar with $1 \%$ potassium tellurite solution and $50 \%$ egg yolk emulsion was used. After inoculation, plates were incubated at $35^{\circ} \mathrm{C}$ for 48 hours. Molds and yeast were analyzed by the Petrifilm ${ }^{\circledR}$ YM (3M®) system and then were incubated at $25^{\circ} \mathrm{C}$ for 7 days. For analysis of Salmonella sp., the samples were pre-enriched in flasks containing $225 \mathrm{~mL}$ of $1 \%$ peptone water sterilized. After $24 \mathrm{~h}$ incubation, the aliquots were transferred to enrichment broths in the selective liquid media (Rappaport Vassiliadis Broth and Selenite Cystine Broth). From each enrichment broth, an aliquot was streaked onto the previously dried surface of plates with Salmonella Shigella, and Brilliant Green Agar, so as to obtain isolated colonies. The plates were then incubated, inverted, at $36 \pm 1^{\circ} \mathrm{C}$ for 18 to $24 \mathrm{~h}$.

Descriptive statistics were performed using percentage values. An analysis was made as to the percentage of the adequacy of the 5 blocks in checklist. For the calculation of adequacy percentages, when "NA" was selected for any item, this was not included in evaluated items counted.

The results of the microbiological analyzes were expressed in $\mathrm{CFU} / \mathrm{g}$ or $\mathrm{CFU} / \mathrm{mL}$. The results obtained were compared with the national standard established by legislation [18].

\section{Results and Discussion}

\subsection{Good Handling Practices}

In street food trades, $72.1 \%$ commercialized beverages (coconut water, soft drinks, juices, mineral water, coffee, beer and liquor), meats (hot dogs, steak, hamburgers, meats), candy, pies, cakes, and salted preparations. Other commercialized products such as cooked corn, pasta, and popcorn. In $40 \%$ of street food trades, there was only one food handler, $38 \%$ had two, and $22 \%$ had three or more. The average percentage of adequacy for checklist applied in street food trades was equal $44 \%$. In addition to the general evaluation, the checklist was block classified (Figure 1). The block that received the lowest percentage of adequation was 'Sanitary license' (Figure 1).

In the area of most points of sale, the presence of garbage and animals was observed. Another inadequate item observed was the presence of uncovered dumps in $51.6 \%(\mathrm{n}=31)$ of street trades. In the same item, it was observed that in $11.6 \%(n=7)$ of trades there were dumps in suitable conditions (lid, pedal and covered with plastic bags). Also, was observed there was no recipient for trash or existed bags or cardboard boxes. This fact is problematic since garbage accumulated and inadequately conditioned is a risk factor to attract insects and rodents for street food trades [19]. A similar failure was observed in the study conducted in Taubaté, São Paulo, Brazil in which only $18.4 \%$ of the street trades had a bin with a lid [19].

Aluko et al [20] found that $73.8 \%$ of the trades visited in Nigeria shared utensils among raw and cooked products. Monteiro [21] observed that in $31.2 \%$ of the eastern region of Belo Horizonte-MG there were no dumps with a lid. Establishments without signs of insects and rodents are characteristics that demonstrate hygienic and sanitary conditions and care aimed at the prevention of consumer health. 


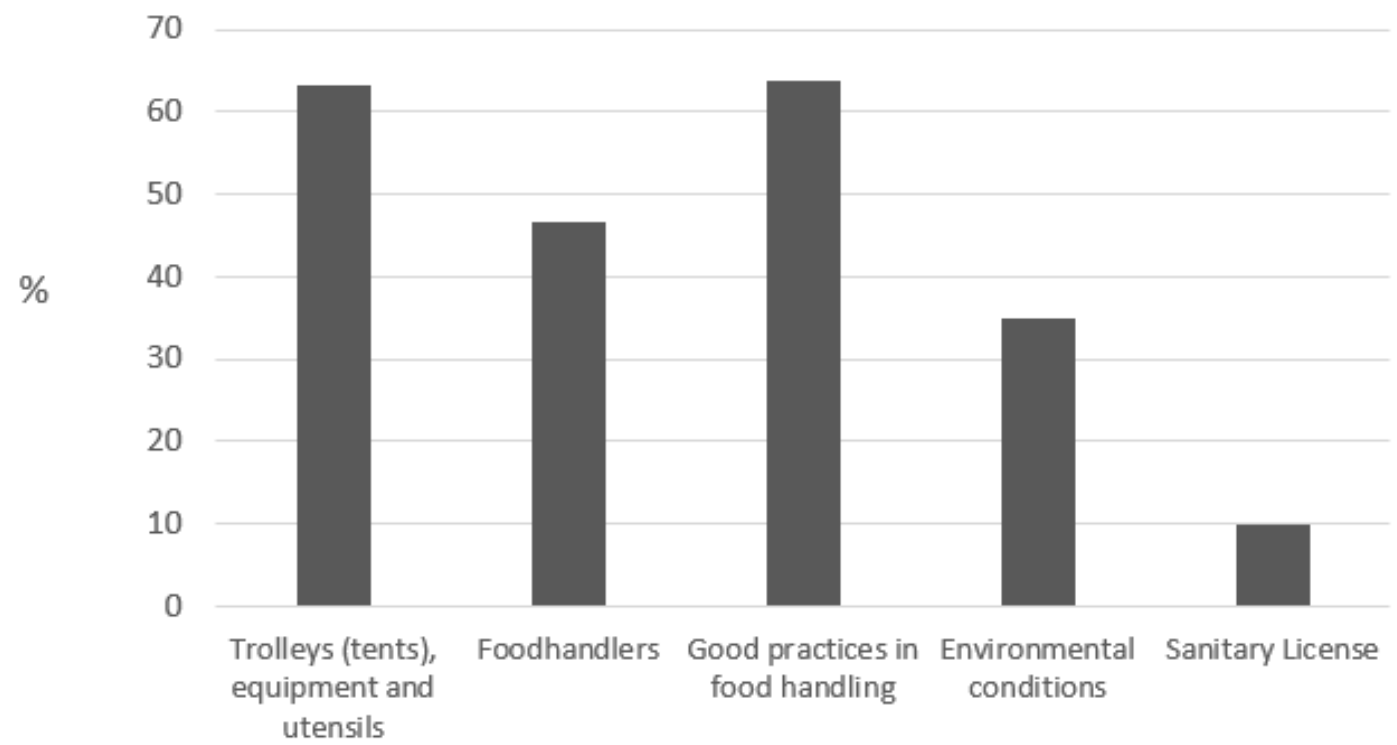

Figure 1. Percentage of the adequacy of the five checklist blocks evaluated in street food trades located in Vitória, Espírito Santo, Brazil

In the evaluation of the "food handlers" block, it was observed that $95 \%(\mathrm{n}=57)$ of the evaluated trades presented inadequacy in the execution of hand washing before handling food. Elsewhere, vendors used strategies such as gloves and alcohol gel before returning to food handling. According to legislation [13], handlers must adopt procedures that minimize the risk of contamination of prepared foods by antisepsis of the hands and by the use of disposable utensils or gloves [8]. The absence of hand washing and food and money handling by the same trader lead to the highest risk of contaminated hands [12]. Silva et al. [22] found that $22.6 \%$ of vendors did not disinfect their hands while are working and $80.2 \%$ touch food and money at the same time. This situation was commonly observed in the Vitoria trades since in $40 \%$ (n $=24$ ) of the evaluated trades there was only one seller.

Commercialization place is a critical point for possible contamination of street food since it can present insufficient environmental conditions and can attract insects and rodents [2]. The absence of insect and vector protection was additional identified fault in the food production. Due to environmental contamination and nonexistence of running water or potable water storage, the food safety conditions in these locations are unreasonable [23].

Regarding personal hygiene, it was observed that in only $41.7 \%(n=25)$ of the sales points there was adequacy. In these places was observed inappropriate conditions about personal hygiene. They do not cover mustaches, beard or long hair with hair net and have long nails. Some of the vendors wear jewelry while handling food. A similar result was found in a study by Brandalize et al [24] which evaluated itinerant trades in the city of Curitiba, Paraná, Brazil, and observed $44.9 \%$ of food handlers compliance with this item. According to Resolution 216/2004 [13], food handlers must have short and unglazed nails; and before food handling, all personal adornment objects must be removed.

In the evaluation of the block referring to "trolleys (tents), equipment and utensils" it was observed that in $98 \%(n=53)$ of the points of sale, the hygiene of the utensils was not carried out during the food commercialization. In addition, in $62 \%(n=36)$ of the itinerant trades, utensils such as pickers, spoons, and knives were exposed to environmental conditions without protection against possible contamination. Poorly cleaned surfaces and benches represent a risk of food contamination $[2,8,19]$. Therefore, the hygiene surfaces are considered critical in street food and care should be applied to prevent contamination and proliferation of microorganisms [16]. It is important that the utensils are covered during storage to prevent them from coming in contact with dust suspended by the wind and insects landing on them [25].

Regarding the evaluation of good practices in food handling, in $73 \%(n=44)$ of street food places the activities of the vendors can favor cross-contamination because were not standardized. Cross-contamination risk harms public health [26].

Performed with the required frequency in $48 \%(n=29)$ of the street trades. This fact, according to Brandalize et al. [24], can contribute to the accumulation of residues. We observed that $63 \%$ of the street traders evaluated did not carry out the cleaning preparation area. In a research conducted in Uberaba, Minas Gerais, Brazil, in 70\% of the visited points were observed not satisfactorily hygienization procedure [15].

In this study was observed that most of the itinerant trades $(90 \%)$ did not keep the license to operate the vehicle or equipment in a place visible to the public. In a study conducted by Silva et al. [27] it was found that $75 \%$ of street vendors operated without health surveillance regulations. In this way, health surveillance assesses the condition of establishments and existing protection practices for risk prevention [28]. Therefore, itinerant trades, because they provide health-related services, require the sanitary license for proper functioning. In establishments that do not exist licensing with the sanitary surveillance, control and inspection actions do not occur, so the final product may present health risks to society [28].

Despite the importance of the sanitary food control, there is no specific federal legislation for itinerant 
commerce in Brazil, and sanitary control of this segment is the responsibility of municipalities. In Vitória, Espírito Santo, Brazil, there is legislation for food trade. However, there are no specific regulations for the preparation, preservation and sale of such foods.

\subsection{Microbiological Quality of Food}

The main foods traded by street vendors in Vitória-ES, identified from the checklist, were savory snacks, coconut water, and hot dogs. It was observed that savory snacks (like 'coxinha', 'kibe', esfiha and others commonly consumed in Brazil) were prepared at home and sold on the streets. For coconut water, frequently marketed in coastal cities of Brazil, this was obtained from the coconut that was cut at the time of the commercialization and put in equipment to promote cooling. Hot dogs were assembled at the time of sale, but the stuffing and sauces were prepared before commercialization. It is important to note that, in many occasions, these trades do not have an appropriate place for food storage. These situations may have favored the occurrence of microorganisms in the food analyzed (Table 1).

There is no established standard legislation for coliforms at $35^{\circ} \mathrm{C}$. However, these microorganisms are important because can indicate the hygienic and sanitary conditions during product processing or post-processing. These microorganisms can be transmitted by the hand of food handlers with unsatisfactory hygiene habits, by insects or water. However, they can be destroyed by heat. The presence of coliforms $35^{\circ} \mathrm{C}$ was verified in all food groups analyzed. This result points to failures in food handling. In agreement with this microbiological result, the checklist of good practices showed that in $95 \%(n=57)$ of the evaluated sites there was no adequacy for the correct hygiene of the hands before handling food. This problem probably contributed to the obtained results.

The highest load of this microbial group was identified in hot dogs. In a study conducted by Ferretti and Alexandrino, in Terra Boa, Paraná, Brazil, 100\% of the hot dogs analyzed had coliforms at $35^{\circ} \mathrm{C}$ [28]. In a study developed by Alves, it was verified the presence of coliform contamination at $35^{\circ} \mathrm{C}$ in $30 \%$ of the samples of hot dogs of ambulant trades of the city of Uberaba-MG [29].

The maximum permitted limit by the legislation for coliforms $45^{\circ} \mathrm{C}$ is $10^{2} \mathrm{MPN} / \mathrm{g}$. In the present study, E. coli analysis was conducted. However, none of the analyzed samples present these microorganisms. Kothe et al. [30] observed that $30 \%$ of the analyzed samples were above this limit for fecal coliforms.

Therefore, the presence of Staphylococcus sp. in all analyzed food groups indicate inadequacies in post-processing. This problem could be common in foods that have passed through higher temperatures, such as salty foods, besides sausages, and hot dog sauces. Kothe et al [30] find $25 \%$ of samples unsuitable for consumption because of attained levels higher than specified by Brazilian legislation. The current legislation, RDC $\mathrm{n}^{\circ}$ $12 / 2001$ of ANVISA, recommends that $10^{3} \mathrm{CFU} / \mathrm{g}$ should be the maximum value per gram for positive coagulase Staphylococcus aureus [9]. In the evaluation of Staphylococcus sp. not all salty and not all coconut waters showed high counts. According to Santana et al. enterotoxins are detectable in foods with $S$. aureus populations above $10^{5} \mathrm{CFU} / \mathrm{g}$ of food and this criterion includes all hot dogs analyzed [31].

The presence of molds and yeasts was observed in all food groups. Brazilian legislation does not establish limits on these microorganisms in the analyzed foods [9]. Molds and yeasts are undesirable in foods because they are capable of producing enzymes that cause food spoilage [32]. Molds can also produce mycotoxins which can cause harmful biological changes in both humans and animals [32]. Food after cooking should be stored at temperatures above $60{ }^{\circ} \mathrm{C}$ to minimize the growth of microorganisms. Brazilian legislation also recommends that, for hot preservation, food should be subjected to a temperature of more than $60^{\circ} \mathrm{C}$ for a maximum of 6 (six) hours [8]. However, only $10 \%(n=1)$ of the savory snacks analyzed in this work remained stored in oven. $10 \%(\mathrm{n}=1)$ remained in the thermal box and was heated in the microwave at the time of purchase. In this research, $80 \%$ $(\mathrm{n}=8)$ savory snacks were stored in switched stoves, styrofoam box, plastic or unprotected container.

Salmonella sp. was not detected in food samples. Loukieh et al [33] observed unsatisfactory results levels of foodborne pathogens in food sold in Beirut, Lebon.

The microbiological results of the present study showed a higher level of contamination in hot dogs. Although they are not considered high-risk preparation, since the elaboration process is simple, many steps are not performed and involve little handling. In addition, the ingredients that make up this sandwich are generally industrialized, which may generate less risk, and the sausage is heated and kept warm for snacking. However, due to manipulation failures, the hot dogs had the highest microbial load for Staphylococcus spp. and coliforms at $35{ }^{\circ} \mathrm{C}$. Results indicated unsatisfactory levels and this fact could be related to unproper environmnental conditions, money handling and inappropriate methods of storage.

Microbiological food quality is an important factor to define safety. The presence of foodborne pathogens causes risk on public health [33]. The many complexities include the exposure of raw supplies to unprotected environmental conditions and bad practices can favor the unsatisfactory quality of food [33,34].

Table 1- Microbiological analysis results (CFU/g or CFU/mL) of foods sold in street trades of Vitória, Espírito Santo, Brazil.

\begin{tabular}{lcccc}
\hline Food & Coliform a $35^{\circ} \mathbf{C}$ & E. coli & Staphylococcus sp. & Molds and yeasts \\
\hline $\begin{array}{l}\text { Savory Snacks } \\
(\mathrm{n}=10)\end{array}$ & $<10^{1}-1,5 \times 10^{4}$ & $\mathrm{Nd}$ & $1 \times 10^{2}-1,6 \times 10^{5}$ & $8,0 \times 10^{1}-2,4 \times 10^{4}$ \\
$\begin{array}{l}\text { Coconut Water } \\
(n=6)\end{array}$ & $9,6 \times 10^{2}-2,5 \times 10^{4}$ & $\mathrm{Nd}$ & $<10^{2}-2,0 \times 10^{4}$ & $<10^{2}-1,4 \times 10^{4}$ \\
$\begin{array}{l}\text { Hog dog } \\
(n=6)\end{array}$ & $2,3 \times 10^{4}-2,5 \times 10^{4}$ & $\mathrm{Nd}$ & $4,3 \times 10^{4}-1,7 \times 10^{5}$ & $\mathrm{Absent}$ \\
\hline
\end{tabular}

$* \mathrm{Nd}=$ not detect. 


\section{Conclusion}

The sanitary and hygienic conditions of the itinerant trade were considered inadequate due to failures in handling and storage practices as well as the microbiological contamination. The main inadequacy detected by the checklist was related to the absence of a sanitary license and environmental conditions. The results of this research may contribute to alert the population and health authorities about the risk of street food in the city of Vitoria-ES. There is also a need for capacity-building of retailers, the development and application of adequate sanitary standards for the street food.

\section{Acknowledgements}

We thank Pro-Reitoria de Extensão of Universidade Federal do Espírito Santo for all their support. The authors are grateful for the participation of street vendors.

\section{Authors' Contributions}

Jhenifer de Souza Couto Oliveira and Jackline Freitas Brilhante de São José conceived the study and its original design, drafted the initial form and all revisions of this paper. Jhenifer de Souza Couto Oliveira collected and analyzed the data. Jhenifer de Souza Couto Oliveira and Jackline Freitas Brilhante de São José reviewed and approved the final manuscript.

\section{References}

[1] World Health Organization (WHO). 'Food for the cities: Street foods'. Available:

http://www.fao.org/fcit/food-processing/street-foods/en/.

[Accessed Sep. 2, 2018]

[2] Cortese, R.D.M., Veiros, M.B., Feldman, C. and Cavalli, S.B. 'Food safety and hygiene practices of vendors during the chain of street food production in Florianopolis, Brazil: A cross-sectional study', Food Control, 62 (1), 178-186. 2016.

[3] Al Mamun, M., Rahman, S.M.M. and Turin, T.C. 'Microbiological quality of selected street food items vended by school-based street food vendors in Dhaka, Bangladesh'. International Journal of Food Microbiology, 166, 413-418.2013.

[4] Auad, L.I., Ginani, V. C., Leandro, E. S., Farage, P., Nunes, A. C. S. and Zandonadi, R. P. 'Development of a Brazilian Food Truck Risk Assessment Instrument'. International Journal of Environmental Research. Public Health, 15, 2624.2018.

[5] World Health Organization (WHO). Essential Safety Requirements for Street Vended Foods (Revised Edition). Food Safety Unit, Division of Food and Nutrition, WHO, Geneva. 1996

[6] Okojie P.W. and Isah E.C., "Sanitary Conditions of Food Vending Sites and Food Handling Practices of Street Food Vendors in Benin City, Nigeria: Implication for Food Hygiene and Safety," Journal of Environmental and Public Health, vol. 2014. Article ID 701316, 6 pages.2014,

[7] Trafialek, J., Drosinos, E. H. and Kolanowski, W. 'Evaluation of street food vendors' hygienic practices using fast observation questionnaire'. Food Control, 80, 350-359. 2017.

[8] São José, J.F.B. 'Contaminação microbiológica em serviços de alimentação: importância e controle'. Nutrire Revista da Sociedade Brasileira de Alimentação e Nutrição, 37(1). 2012

[9] Brasil, Ministério da Saúde. 'Surtos de Doenças Transmitidas por Alimentos no Brasil'. Available:

http://portalarquivos.saude.gov.br/images/pdf/2016/junho/08/Apre senta----o-Surtos-DTA-2016.pdf. [acessed 2 fev 2018].
[10] Gonçalves, J.M., Rodrigues, K.L., Demoliner, F., Rossales, R., Almeida, Â.T.S, Buchweitz, M.RD. 'Hygienic and sanitary conditions in the hospital foodservice: relationship between good practices and microbiological quality'. Journal of Food Safety, 33(4), 418-422. 2013.

[11] Jahan, M., Rahman, M., Rahman, M. et al. Microbiological safety of street-vended foods in Bangladesh. J Consum Prot Food Saf (2018) 13: 257.

[12] Souza, G.C. de, Santos, C.T.B. dos, Andrade, A.A., Alves, L. 'Comida de rua: avaliação das condições higiênico-sanitárias de manipuladores de alimentos'. Ciência \& Saúde Coletiva, 20(8), 2329-2338. 2015

[13] Brasil, Ministério da Saúde. Resolução - RDC no 216, de 15 de setembro de 2004. Dispõe sobre Regulamento Técnico de Boas Práticas para Serviços de Alimentação. Diário Oficial da Republica Federativa do Brasil 2004.

[14] Torres, S.A.M. 'Locais de preparação e comércio de cachorroquente: avaliação higiênico-sanitária e o ponto de vista do consumidor' [Dissertação]. Viçosa: Universidade Federal de Viçosa. 2008.

[15] Pierre LT. Condições higiênico-sanitárias de alimentos prontos para consumo comercializados por ambulantes no município de Ouro Preto-MG. Biblioteca Digital UFMG 2008 Available: http://www.bibliotecadigital.ufmg.br/dspace/handle/1843/MAFB7PZG7N. [Acessed Apr. 04, 2017].

[16] Downes, F.P., Ito, K. 'Compendium of methods for the microbiological examinations of foods'. 2001.

[17] AOAC - Association of Official Analytical Chemists. Official methods of analyses of the Association of Analytical Chemists (18th ed.), 2005.

[18] Brasil, Ministério da Saúde. 'Resolução - RDC no 12, de 02 de janeiro de 2001. Aprova o Regulamento Técnico sobre Padrões Microbiológicos para Alimentos'. Diário Oficial da Republica Federativa do Brasil. 2001.

[19] Franco, C.R. and Ueno, M. 'Comércio ambulante de alimentos: condições higiênico-sanitárias nos pontos de venda em TaubatéSP'. Journal of Health Sciences, 12(4). 2015.

[20] Aluko, O.O., Ojeremi, T.T., Olakele, D.A. and Ajidagba, E.B. 'Evaluation of food safety and sanitary practices among food vendors at car parks in Ile Ife, southwestern Nigeria'. Food Control, 40, 165-171. 2014.

[21] Monteiro, M.A.M. 'Caracterização do Comércio Ambulante de Alimentos em Belo Horizonte-MG. Demetra: Alimentação, Nutrição \& Saúde, 10(1), 87-97. 2015.

[22] Silva, S.A., Cardoso, R.C.V., Góes, J.A.W., Santos, J.N., Ramos, F.P., Jesus, R.B., Vale, R.S., Silva, P.S.T. Street food on the coast of Salvador, Bahia, Brazil: A study from the socioeconomic and food safety perspectives. Food Control, 40,78-84, 2014;

[23] Proietti, I., Frazzoli C. and Mantovani A. 'Identification and management of toxicological hazards of street foods in developing countries'. Food Chemistry and Toxicology, 63, 143-52. 2014.

[24] Brandalize, P.C., Peres, A.P. and Passoni, C.M.S. 'Condições higienicossanitárias do comércio ambulante de alimentos, na feira de artesanato de Curitiba, PR'. Higiene Alimentar, 27(216/217), 54-57. 2013.

[25] Lucca, A. and Torres, E.A.S.F. 'Street-food: the hygieneconditionsof hot-dogs sold in São Paulo, Brazil'. Food Control, 17(4), 312-316. 2006.

[26] Sanlier, N., Sezgin, A. C., Sahin, G. and Yassibas, E. 'A study about the young consumers' consumption behaviors of street foods'. Ciência \& Saúde Coletiva, 23(5), 1647-1656. 2018.

[27] Silva, L.I.M.M. da, Thé, P.M.P., Farias, G.S., Telmos, B.M.A., Fiúza, M.P. and Branco, C.C.C. 'Condições higiênico-sanitárias do comércio de alimentos em via pública em um campus universitário'. Brazilian Journal of Food \& Nutrition, 22(1). 2011.

[28] Ferretti, G.M., Alexandrino, A.M. 'Avaliação da qualidade higiênico-sanitária de cachorros quentes comercializados em via pública no município de Terra Boa-PR'. SaBios-Revista de Saúde e Biologia, 8 (3). 2014.

[29] Alves, T.P. and Jardim FBB. 'Análise microbiológica de cachorros quente comercializados na cidade de Uberaba, MG'. Cadernos de Pós-Graduação da FAZU, 1. 2011.

[30] Kothe, C.I., Schild, C.H., Tondo, E.C. and Malheiros, P.S. 'Microbiological contamination and evaluation of sanitary conditions of hot dog street vendors in Southern Brazil'. Food Control, 62, 346-350. 2016, 
[31] Santana, F.A., Vieira, M.C. and Pinto, U.M. 'Qualidade microbiológica de sanduíches de estabelecimentos com serviço tipo delivery'. Revista do Instituto Adolfo Lutz 74(2), 156-161. 2016.

[32] Kuhn, C.R., Gandra, E.Á., Ferreira, L.R., Bartz, J., Gonzáles, Á.P. and Fontoura, G.C. 'Qualidade microbiológica de lanches comercializados na cidade Pelotas-RS'. Global Science and Technology, 5(3). 2012.
[33] Loukieh, M., Mouannes, E., Jaoudeh, C.A., Wakim, L.H., Fancello F. and Zeidan, M. B. 'Street foods in Beirut city: An assessment of the food safety practices and of the microbiological quality'. Journal of Food Safety, 38, 1-11, 2018.

[34] Hilario, J.S. 'An Evaluation of the Hygiene and Sanitation Practices Among Street Food Vendors Along Far Eastern University (FEU)'. International Journal of Advanced Research, 3(2), 604-615, 2015.

(C) The Author(s) 2019. This article is an open access article distributed under the terms and conditions of the Creative Commons Attribution (CC BY) license (http://creativecommons.org/licenses/by/4.0/). 